\title{
Correction: PILAŠ I, MEDVED I, MEDAK J, PERČEC TADIĆ M, MEDAK D 2016 Ecological, Typological Properties and Photosynthetic Activity (FAPAR) of Common Beech (Fagus sylvatica L.) Ecosystems in Croatia
}

\author{
Ivan Pilaš ${ }^{1^{*}}$, Ivan Medved ${ }^{1}$, Jasna Medak ${ }^{1}$, Melita Perčec Tadić ${ }^{2}$, Damir Medak ${ }^{3}$
}

(1) Croatian Forest Research Institute, Division of Ecology, Cvjetno naselje 41, HR-10450 Jastrebarsko, Croatia; (2) Meteorological and Hydrological Service, Grič 3, HR-10000 Zagreb, Croatia; (3) University of Zagreb, Faculty of Geodesy, Kačićeva 26, HR-10000 Zagreb, Croatia

* Correspondence: e-mail: ivanp@sumins.hr

\begin{abstract}
Citation: PILAŠ I, MEDVED I, MEDAK J, PERČEC TADIĆ M, MEDAK D 2017 Correction: PILAŠ I, MEDVED I, MEDAK J, PERČECTADIĆM, MEDAK D 2016 Ecological, Typological Properties and Photosynthetic Activity (FAPAR) of Common Beech (Fagus sylvatica L.) Ecosystems in Croatia. Southeast Eur for 8 (1): 67. DOI: https://doi. org/10.15177/seefor.17-04

Received: 6 Mar 2017; Accepted: 6 Mar 2017; Published online: 9 Mar 2017
\end{abstract}

The authors would like to add that work presented by Pilaš et al. [1] was supportted in part by Croatian Science Foundation under the project no. 2831 "Climate of the Adriatic Region in its global context" (CARE).
The original paper published on 20 October 2016 will be updated and both versions will be available on the paper webpage. The authors emphasize that this change do not affect the results of this researche, and they apoplogize for any incovinience this change may cause.

\section{REFERENCES}

1. PILAŠ I, MEDVED I, MEDAK J, PERČEC TADIĆ M, MEDAK D 2016 Ecological, Typological Properties and Photosynthetic Activity (FAPAR) of Common Beech (Fagus sylvatica L.) Ecosystems in Croatia. South-east Eur for 7 (2): 73-89. DOI: https://doi. org/10.15177/seefor.16-13 
